\title{
Systemic and Target-Site Pharmacokinetics of Antiparasitic Agents
}

\author{
Valentin al Jalali ${ }^{1}\left[\right.$ ] $\cdot$ Markus Zeitlinger ${ }^{1}[$ (1)
}

Published online: 26 February 2020

(c) The Author(s) 2020

\begin{abstract}
About one-sixth of the world's population is affected by a neglected tropical disease as defined by the World Health Organization and Center for Disease Control. Parasitic diseases comprise most of the neglected tropical disease list and they are causing enormous amounts of disability, morbidity, mortality, and healthcare costs worldwide. The burden of disease of the top five parasitic diseases has been estimated to amount to a total 23 million disability-adjusted life-years. Despite the massive health and economic impact, most drugs currently used for the treatment of parasitic diseases have been developed decades ago and insufficient novel drugs are being developed. The current review provides a compilation of the systemic and target-site pharmacokinetics of established antiparasitic drugs. Knowledge of the pharmacokinetic profile of drugs allows for the examination and possibly optimization of existing dosing schemes. Many symptoms of parasitic diseases are caused by parasites residing in different host tissues. Penetration of the antiparasitic drug into these tissues, the target site of infection, is a prerequisite for a successful treatment of the disease. Therefore, for the examination and improvement of established dosing regimens, not only the plasma but also the tissue pharmacokinetics of the drug have to be considered. For the current paper, almost 7000 scientific articles were identified and screened from which 429 were reviewed in detail and 100 were included in this paper. Systemic pharmacokinetics are available for most antiparasitic drugs but in many cases, not for all the relevant patient populations and only for single- or multiple-dose administration. Systemic pharmacokinetic data in patients with organ impairment and target-site pharmacokinetic data for relevant tissues and body fluids are mostly lacking. To improve the treatment of patients with parasitic diseases, research in these areas is urgently needed.
\end{abstract}

\section{Key Points}

Most available antiparasitic drugs were developed decades ago and novel antiparasitic agents are urgently needed

Tissue pharmacokinetic studies for most antiparasitic drugs are lacking, but they are essential to optimize the treatment of parasitic diseases and we encourage scientists to help fill this gap

There also is a void of studies investigating the pharmacokinetic/pharmacodynamic relationship of antiparasitic agents. Extending the knowledge in this field will improve the treatment of patients infected with parasitic diseases worldwide

Markus Zeitlinger

markus.zeitlinger@meduniwien.ac.at

http://www.meduniwien.ac.at/klpharm/

1 Department of Clinical Pharmacology, Vienna University Hospital, Medical University of Vienna, Waehringer Guertel 18-20, 1090 Vienna, Austria

\section{Introduction}

Parasitic diseases are responsible for a tremendous amount of disability, morbidity, mortality, and healthcare costs worldwide. About one-sixth of the world's population is infected with a neglected tropical disease (NTD) [1]. Although the NTDs as defined by the World Health Organization and Center for Disease Control are not exclusively made up by parasitic diseases, parasitic diseases comprise most of the NTD list. The Global Burden of Diseases Study from 2010 estimates the burden of disease of the top five parasitic diseases (cryptosporidiosis, intestinal nematode infections, leishmaniasis, schistosomiasis, and lymphatic filariasis) to amount to a total 22.94 million disability-adjusted life-years $[2,3]$. Including other parasitic diseases from the group of NTDs, the number adds up to almost 30 million disability-adjusted life-years. This means that 30 million years of healthy life were lost to premature death and disability because of parasitic diseases. Although many parasitic diseases do not directly lead to death, still 248,900 yearly deaths due to parasitic diseases (excluding malaria) are estimated by the authors of the Global Burden of Disease Study [3]. 
Most of the parasitic infections are limited to developing countries in the tropics and subtropics and affect the world's poorest people. For a long time, pharmaceutical companies and industrial nations did not show much interest in developing new antiparasitic drugs and most drugs that are currently used for the treatment of these infections have been developed decades ago. In recent years, major efforts have been made by numerous organizations and initiatives to repurpose old drugs, develop new drugs, and improve the treatment of patients with parasitic disease worldwide.

In many parasitic diseases, the parasite invades certain tissues of the host, causing a variety of different symptoms. For the treatment of these infections, the antiparasitic drug has to reach the target site of the infection, the respective tissue. Therefore, for most parasitic infections, tissue penetration of the antiparasitic drugs is essential for clinical success of the treatment. Pharmacokinetic studies investigating the tissue pharmacokinetics of drugs can be employed to examine and potentially improve existing dosing schedules. This can increase the efficacy of the treatment and decrease the occurrence of drug toxicity. Furthermore, for repurposing of drugs, knowledge of their target-site penetration may be considered as a basis for exploring novel indications. With this review, we aim to accumulate the currently published data on the plasma pharmacokinetics and tissue pharmacokinetics of the globally available antiparasitic drugs.

\section{Methods}

A systematic search for human pharmacokinetic (PK) studies on anti-parasitic drugs in the PubMed US National Library of Medicine database was performed. Antimalarial drugs were excluded from this review because for most of these agents tissue penetration is not relevant and inclusion of all antimalarial drugs would be beyond the scope of this study. Animal tissue PK data are sometimes used to estimate the missing human tissue PK data. However, non-clinical PK data were not included in this review because the transfer of these data to humans has not been investigated thoroughly and could potentially mislead the clinically oriented reader.

Pharmacokinetic studies up to August 2019 were included in this review. The following search terms were used for each individual drug: "drug name" AND pharmacokinetics; "drug name" AND concentrations; "drug name" AND tissue.

A total number of 6904 studies were screened for relevant PK content with the use of the title and abstract (Fig. 1). If studies with potential PK data were identified, these were read in detail and PK parameters were gathered. In this review, only those studies that most accurately display the common dosing schedules and provide the most detail regarding plasma and tissue pharmacokinetics were included. The literature search was limited to publications in English and German. Studies on patients were only included if the study drug was administered for the treatment of a parasitic disease. Only original papers on human subjects were included. Pharmacokinetic studies on children were only included if no comparable study was identified in adults or if children constitute the main treatment population for the respective disease. Studies were excluded if another study in the same compartment and with the same or a very similar dosing schedule was available with a better quality of data or more patients studied.
Fig. 1 Flowchart depicting reviewing and inclusion criteria and the number of articles reviewed

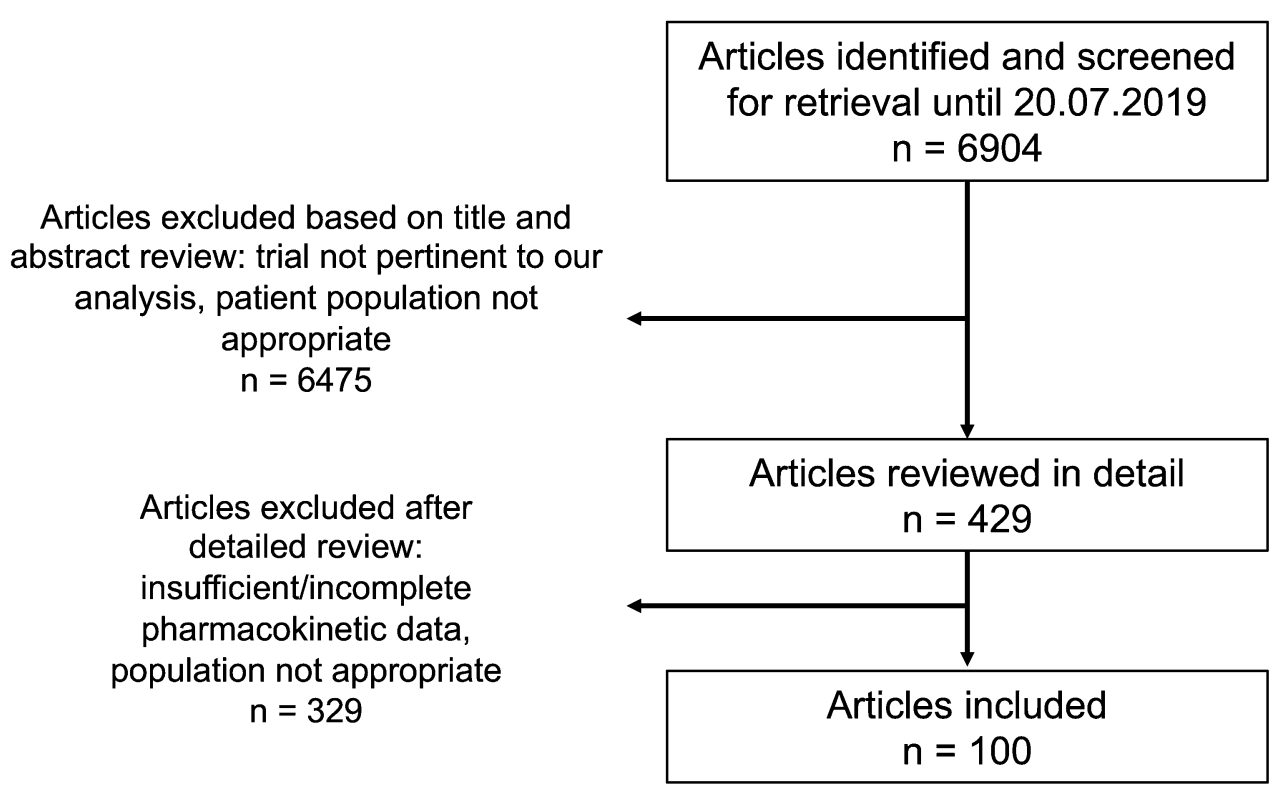




\section{Systemic and Target-Site Pharmacokinetics}

\subsection{Albendazole}

The PK parameters of albendazole (ALB) after oral administration of a single dose (SD) and multiple doses (MD) in healthy volunteers and patients are shown in Table 1 . Studies were included only where ALB was ingested with food because administration with meals is recommended. As a result of the high lipid solubility and low aqueous solubility of ALB, high-fat foods substantially increase absorption of ALB [4]. In a study that investigated the effect of food intake on the absorption of ALB, a fatty meal led to a four-fold increase of the mean plasma area under the concentration-time curve (AUC) [5]. Albendazole is metabolized via a first-pass mechanism in the liver to the active compound ALB sulfoxide. Albendazole is only available for oral administration and the most commonly used dose is $400 \mathrm{mg}$ daily. One study with diethylcarbamazine as concomitant medication was also included because this combination is indicated for certain parasitic diseases.

Albendazole can be used for the treatment of a variety of parasitic diseases. Among them loiasis, filariasis, giardiasis, cysticercosis, toxocariasis, echinococcosis, and soil-transmitted helminthiases. Therefore, the penetration of ALB into numerous target tissues is of relevance. Tissue PK studies for cerebrospinal fluid (CSF), breast milk, and echinococcal cyst fluid were included. Several other studies on the tissue pharmacokinetics of ALB have been published, but those were excluded from the review because of the poor quality of the data (no transfer ratios, only single concentrations measured, no PK calculations).

\subsection{Amphotericin B}

Amphotericin B (AmB) is available as a standard formulation with desoxycholate (AmBD) and two lipid formulations, namely AmB lipid complex (ABLC) and liposomal AmB (LAmB). The lipid formulations have been developed to decrease the nephrotoxic effects of AmBD. All three formulations can only be administered intravenously. Single-dose PK parameters of the three formulations are shown in Table 1, for ABLC, multiple-dose PK parameters are also given.

Therapeutic indications include systemic mycoses and infections with different protozoan pathogens, the most important being visceral leishmaniasis. Tissue penetration studies of AmB have been included in Table 2 for the following compartments: epithelial lung fluid, lung tissue, buccal mucosal tissue, and wound eschar. Two studies on tissue penetration of LAmB into pleural fluid are available in the literature, but they included only one patient each and were therefore not included in our table. The first study found a LAmB penetration ratio of 0.094 by dividing the AUC after $24 \mathrm{~h}$ in tissue by the AUC after 24 $\mathrm{h}$ in plasma. In this study, a patient with pulmonary zygomycosis and empyema was administered multiple doses of $7.5 \mathrm{mg} / \mathrm{kg}$ bodyweight LAmB every second day [6]. In the second study, a patient with sepsis and pneumonia showed a penetration ratio of 0.045 for $\mathrm{LAmB}$. This ratio was calculated by dividing the concentration of LAmB in pleural effusion by the simultaneously measured concentration in plasma [7]. The same study also investigated penetration ratios of $\mathrm{ABLC}$ and $\mathrm{ABCD}$ into pleural effusion. For $A B C D$, five patients were analyzed and a mean ratio of 0.13 was found. The study included only one patient with ABLC with a penetration ratio of 0.45 . Because this study does not include the exact dosing schedules and for LAmB and ABLC only one patient was studied, it was not included in Table 2 [7].

Only one study was identified in patients with organ impairment. This study is not shown in Table 3 because it was conducted in patients with continuous venovenous hemodiafiltration. The authors of this study report a half-life of $48.2 \mathrm{~h}$, a clearance of $31 \mathrm{~L} / \mathrm{h}$, and a volume of distribution of $1607 \mathrm{~L}$ after a dose of $5 \mathrm{mg} / \mathrm{kg}$ bodyweight of ABLC [8].

\subsection{Benznidazole}

Benznidazole (BZD) belongs to the group of nitroimidazole anti-parasitic agents and is mainly used for the treatment of Chagas disease, an infection with Trypanosoma cruzi.

It is only available as an oral formulation and the usual dose is $5-10 \mathrm{mg} / \mathrm{kg}$ bodyweight per day in two divided doses. Detailed PK data after multiple doses have not been published; therefore, only SD PK data are provided in Table 1.

Trypanosoma cruzi can penetrate the central and peripheral nervous system and smooth muscle in the heart, oesophagus, and colon. However, thorough studies on tissue pharmacokinetics could not be identified, except for one penetration study into breast milk (Table 2).

\subsection{Diethylcarbamazine}

Diethylcarbamazine (DEC) is available as an oral and intravenous formulation; however, currently, only oral use is recommended. Oral doses from 2 to $6 \mathrm{mg} / \mathrm{kg}$ bodyweight are usually used. Data of two SD PK studies in healthy volunteers are provided in Table 1 . Two studies investigating the plasma pharmacokinetics of DEC in patients with moderate and severe renal impairment could be identified (Table 3 ). 


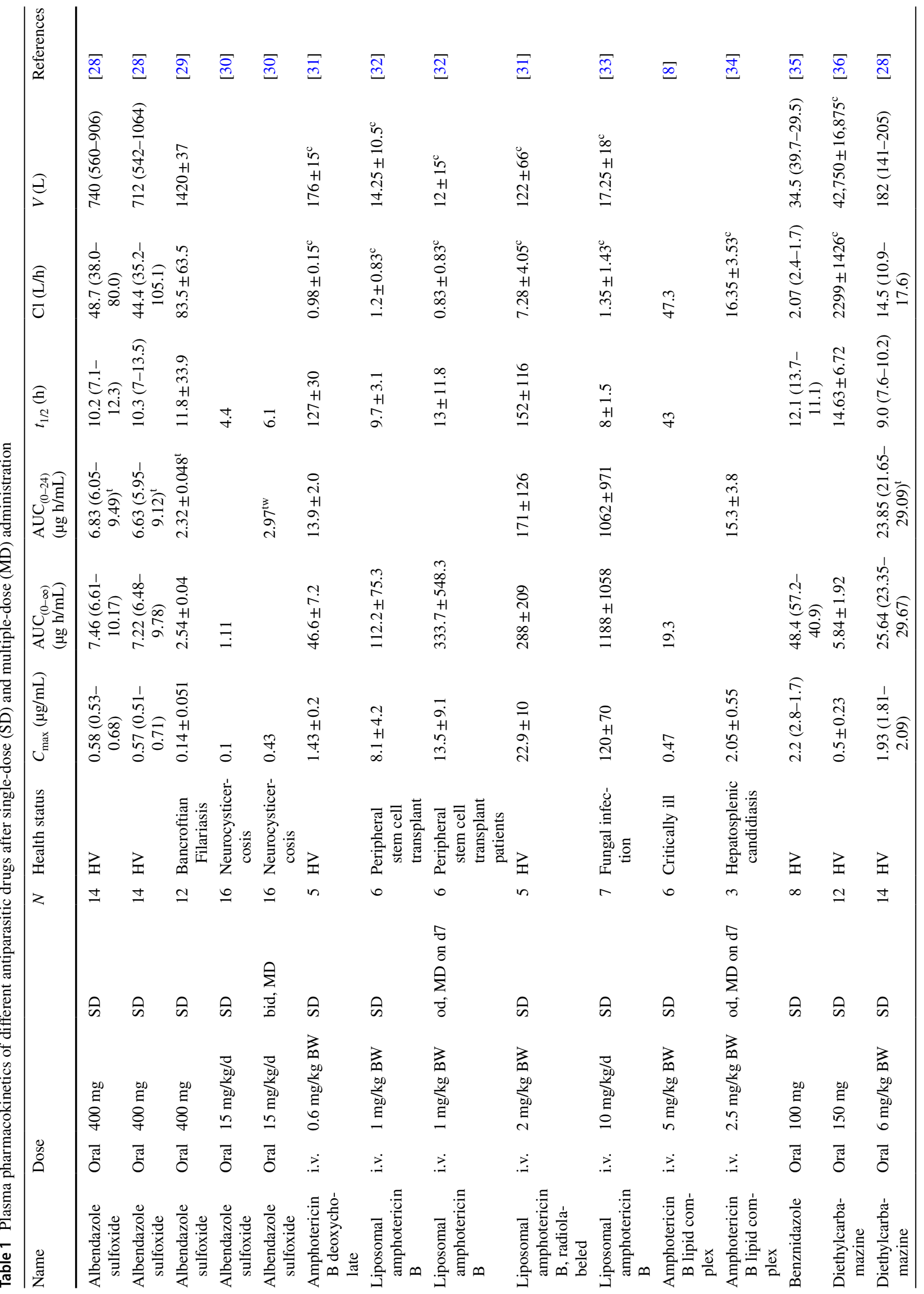




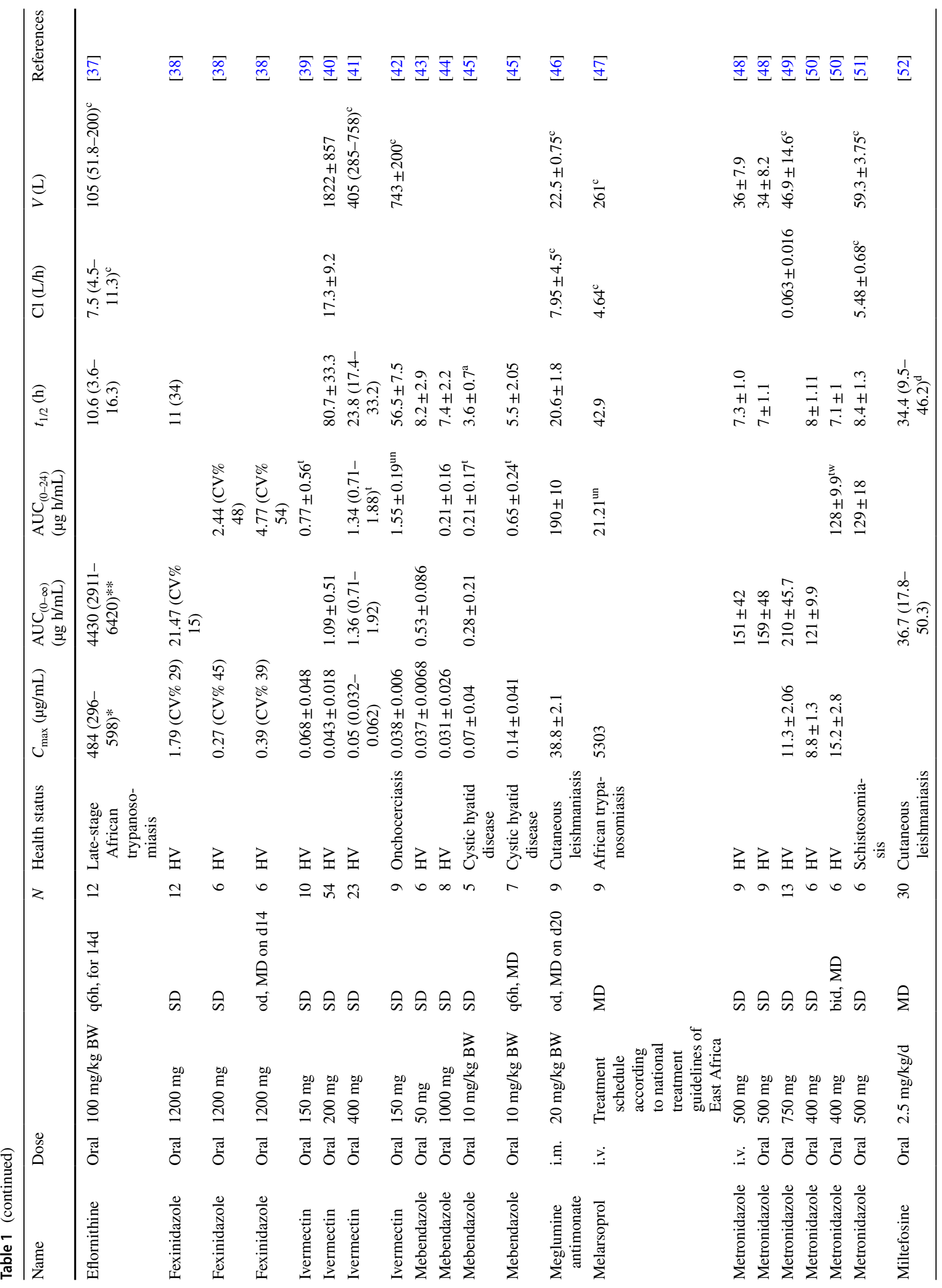




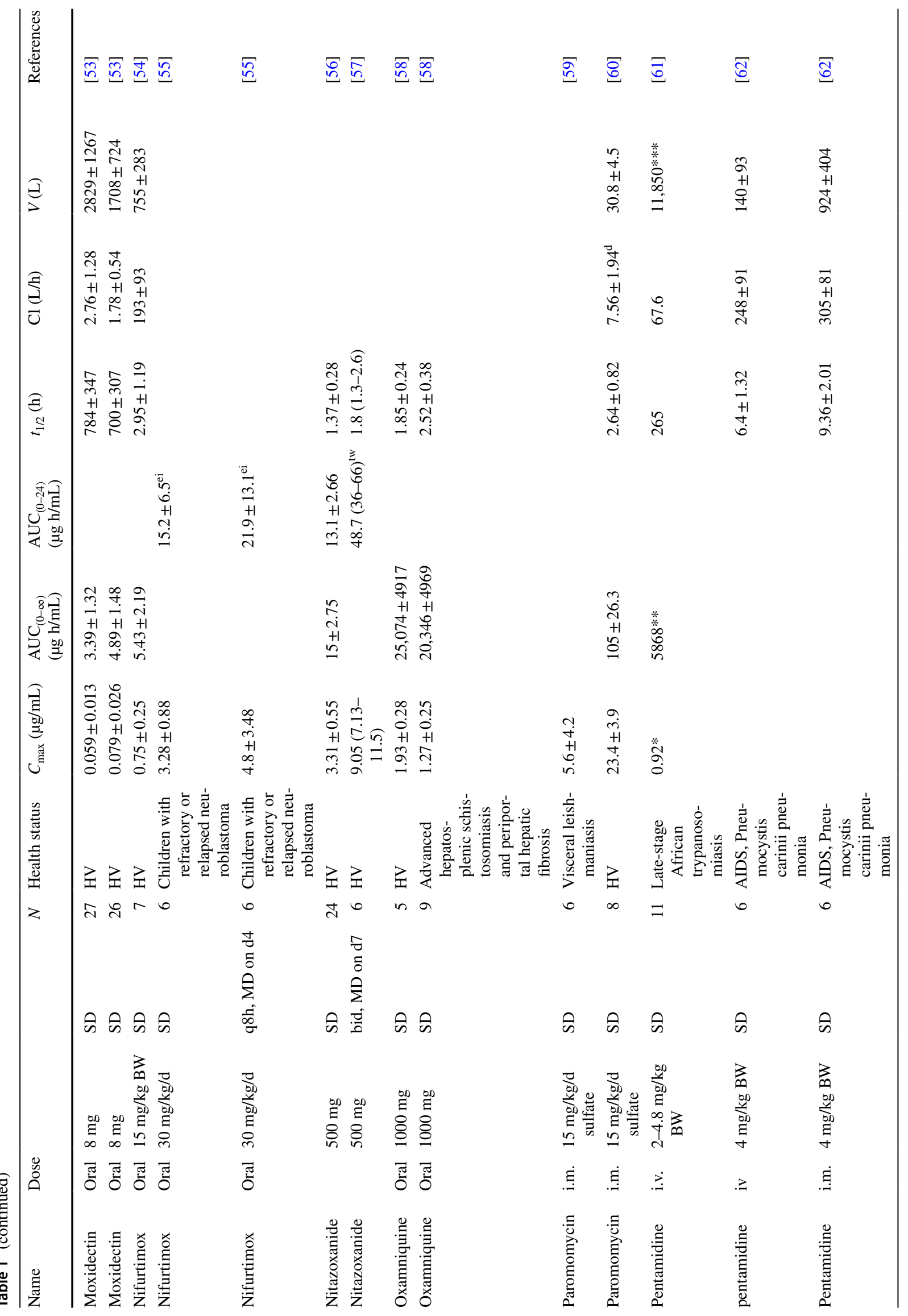




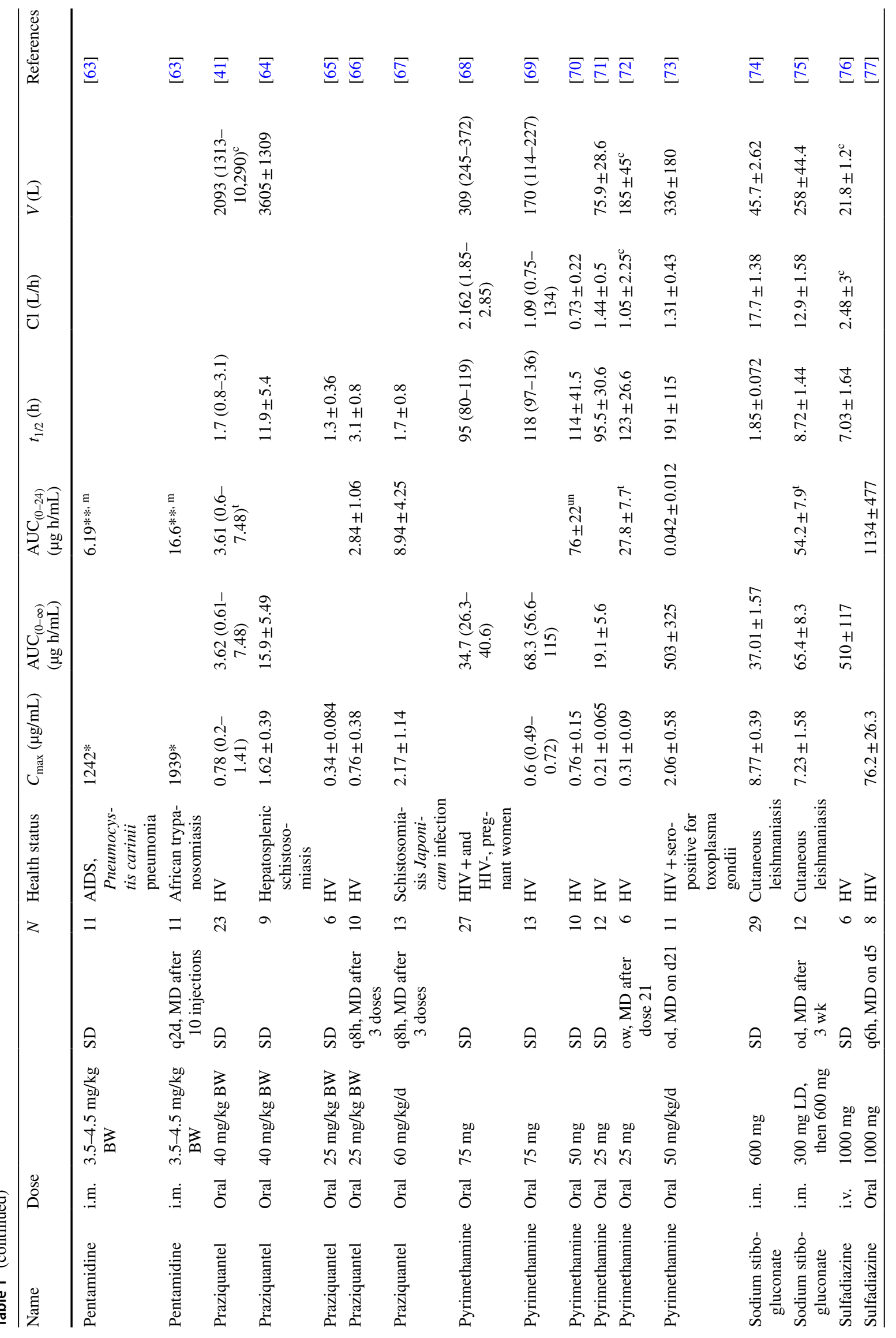




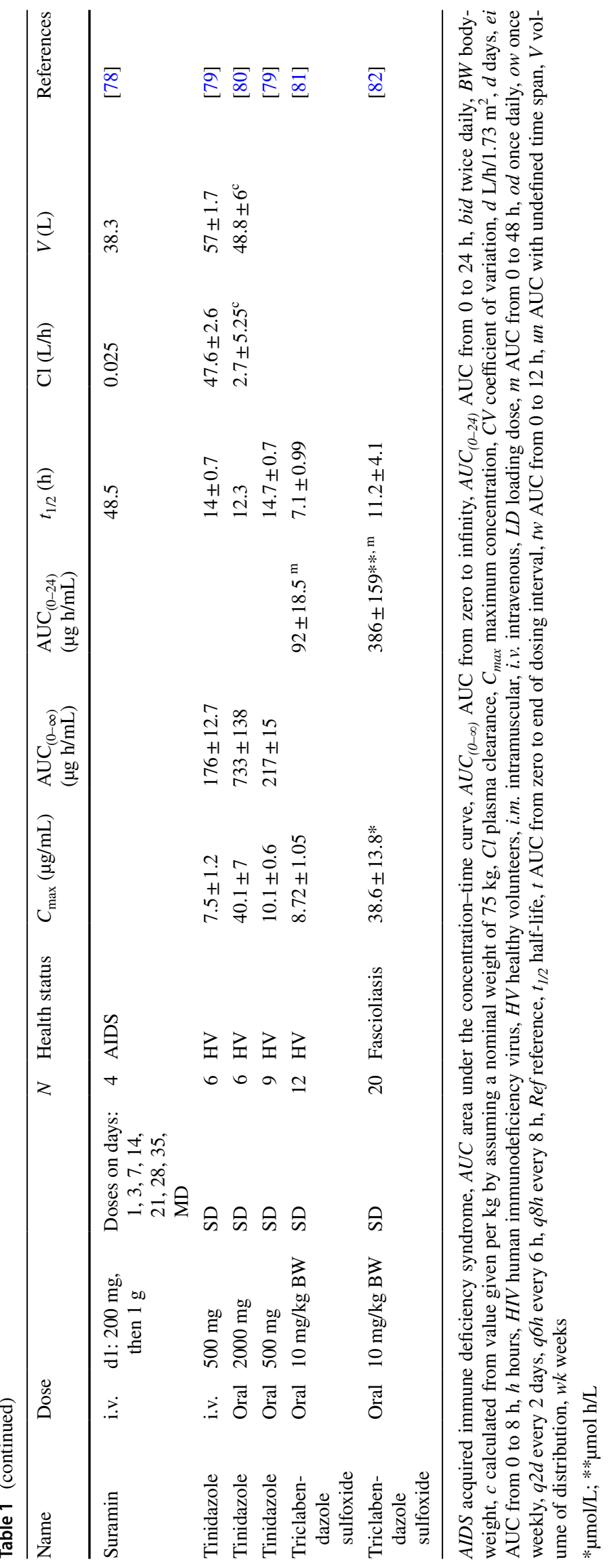




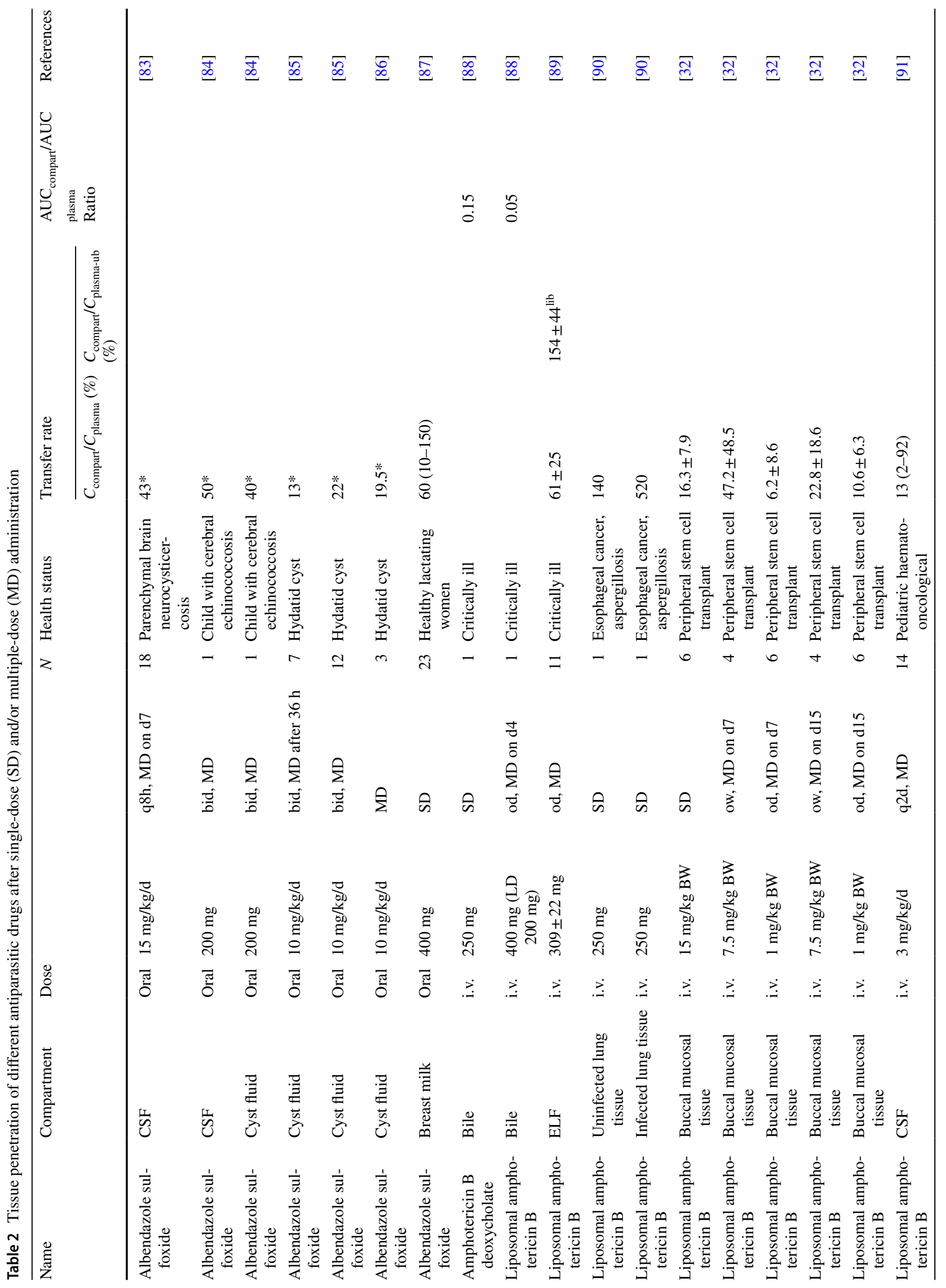




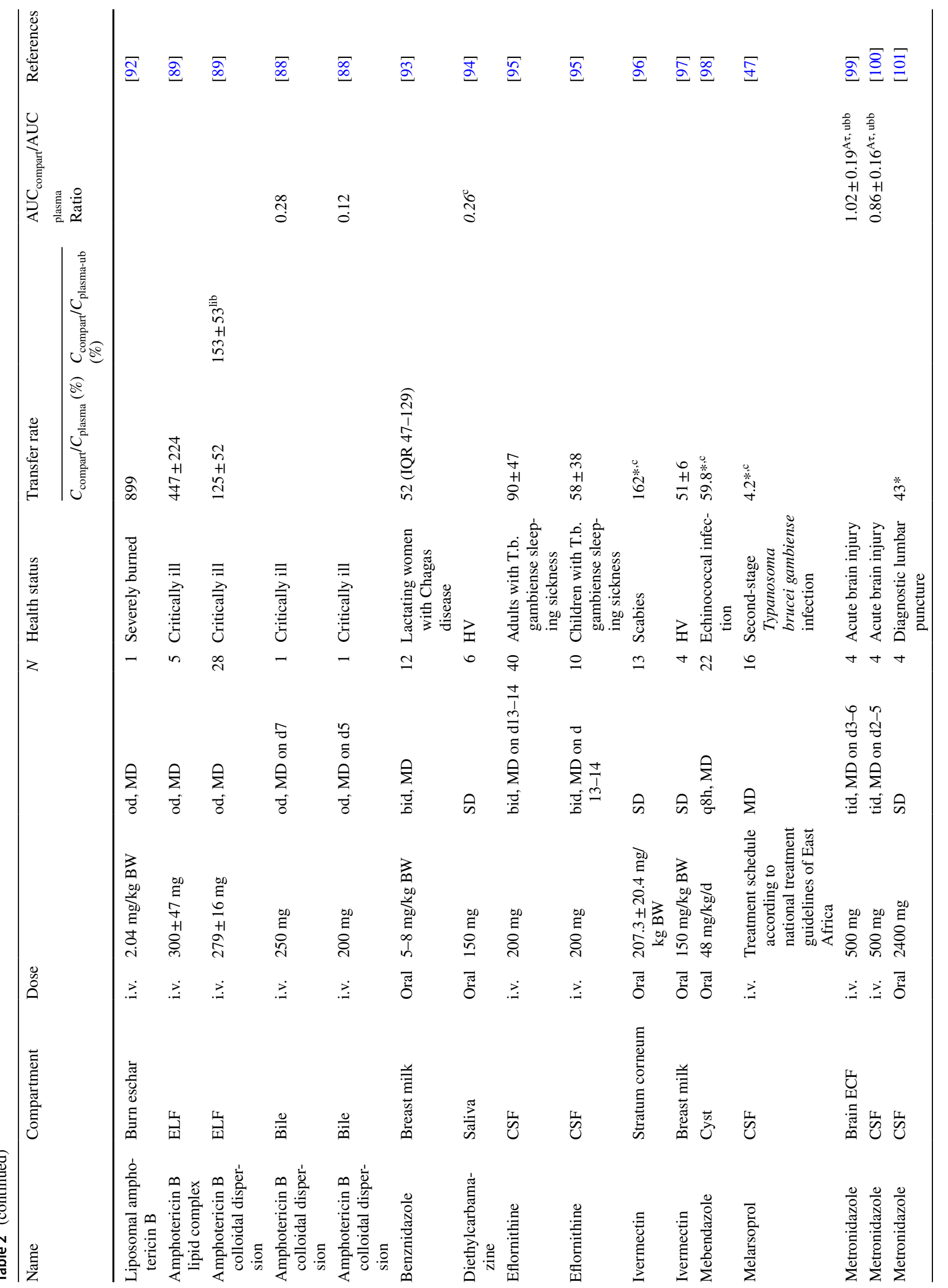




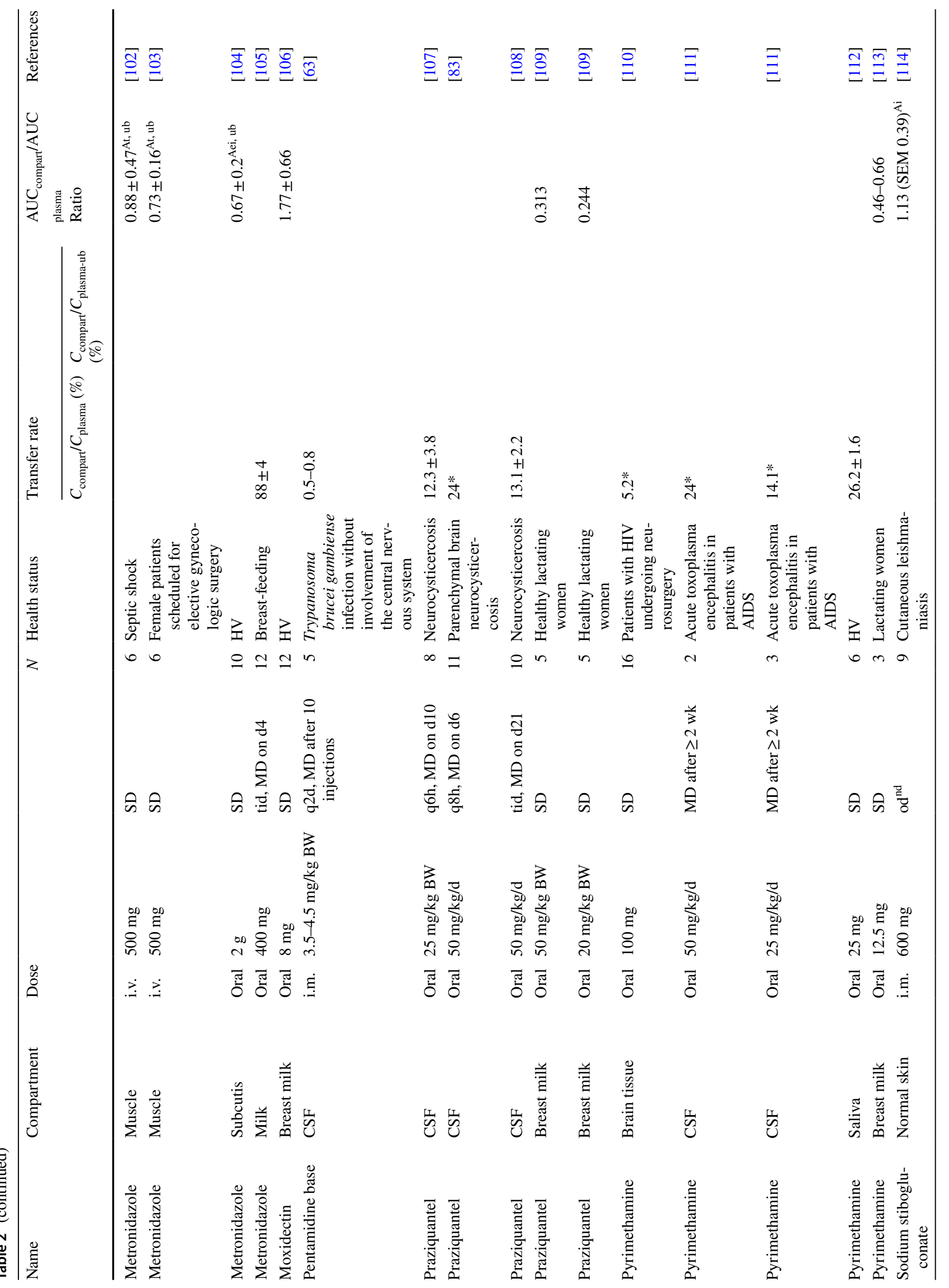




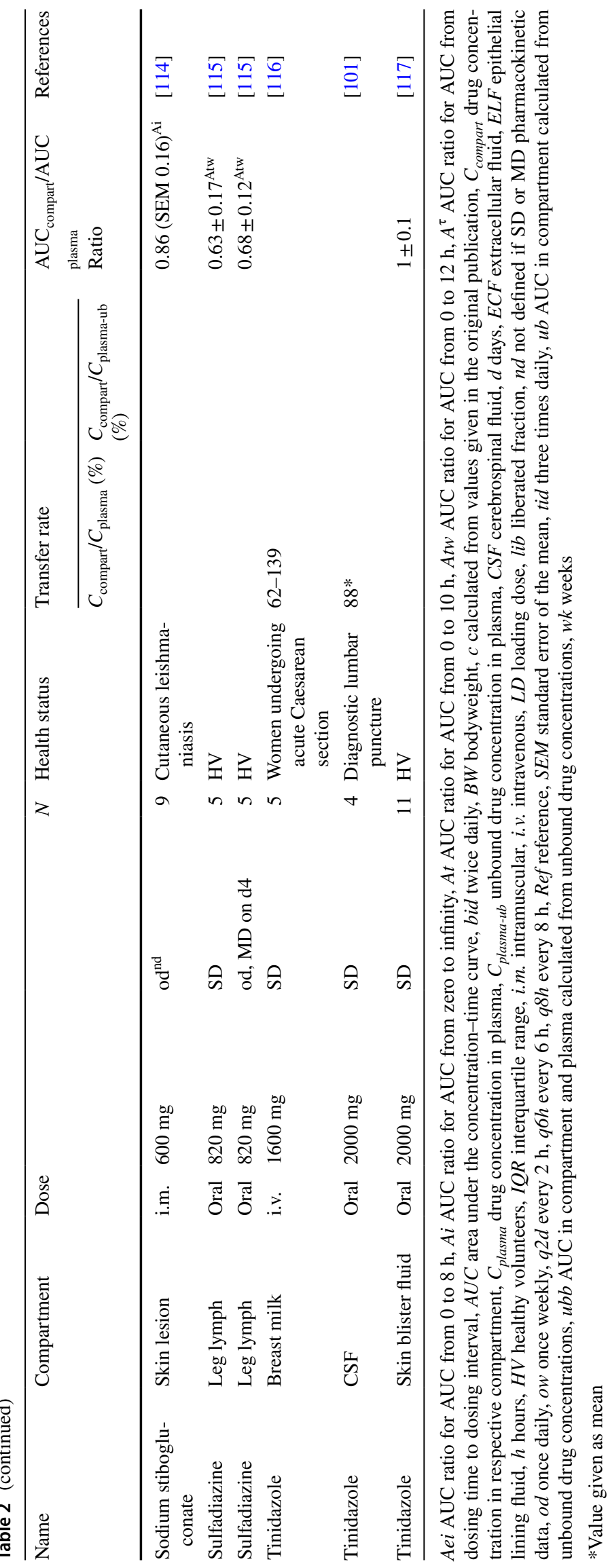




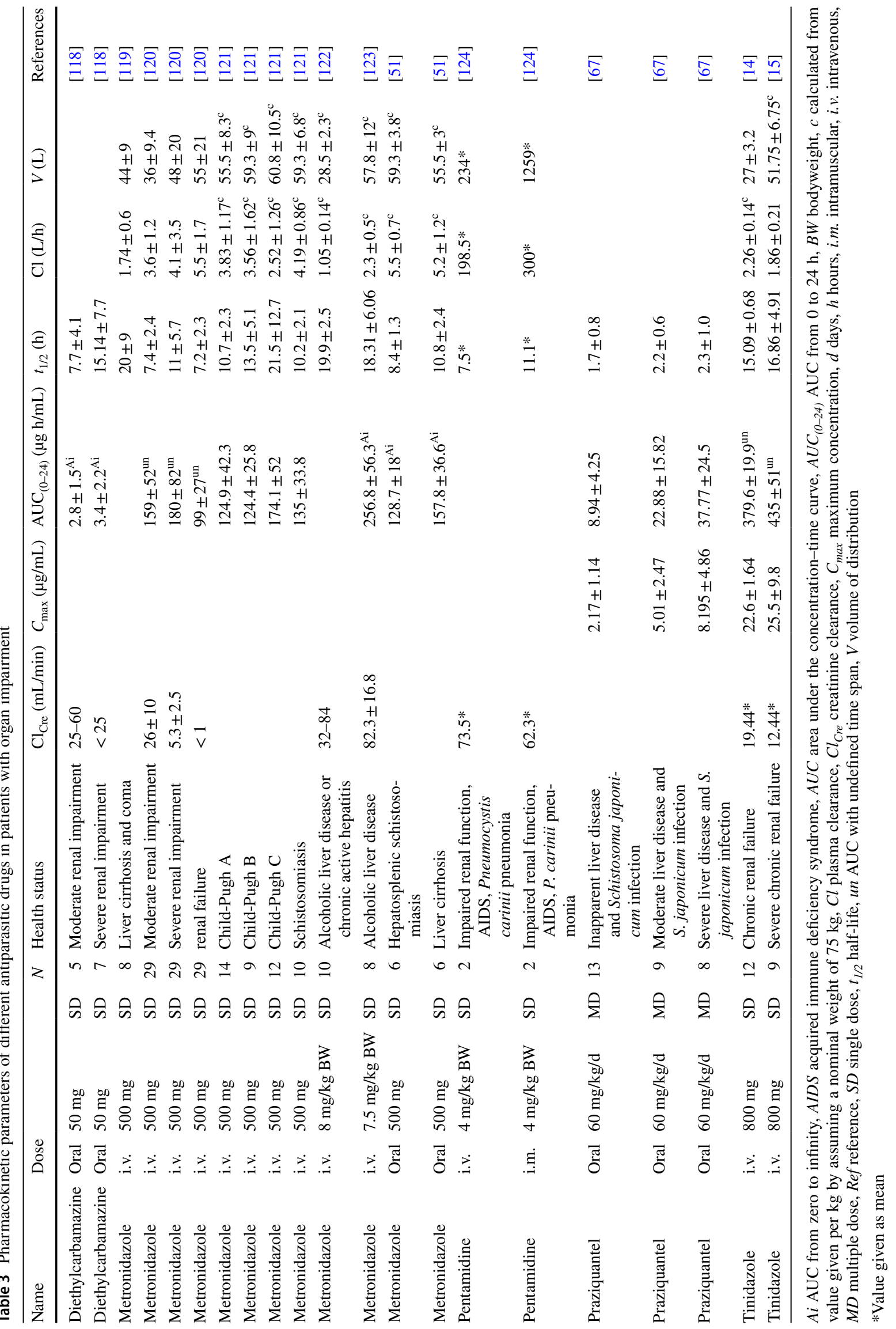


Diethylcarbamazine can be used for the treatment of different filarial diseases, such as lymphatic filariasis, loiasis, tropical pulmonary eosinophilia, and onchocerciasis. No tissue $\mathrm{PK}$ studies could be identified that met our requirements, except for one study that investigated the penetration of DEC into saliva (Table 2). Tissue penetration of the drug would however be crucial to successfully treat the above-named parasitic infections.

\subsection{Eflornithine}

Eflornithine (EFO) can be administered orally or intravenously. It is used for the treatment of African trypanosomiasis (HAT) caused by Trypanosoma brucei gambiense. Only one plasma PK study after multiple administration of the drug has been identified that provides sufficient detail (Table 1).

Trypanosomes can cross the blood-brain barrier and penetrate into the CSF leading to neurological symptoms. To treat those infections, sufficiently high drug concentrations in CSF are of utmost importance. Two studies were identified that investigated CSF concentrations of EFO (Table 2).

\subsection{Fexinidazole}

Fexinidazole (FEX) is a 5-nitroimidazole derivative and can only be administered orally. It was approved in 2018 for the treatment of Trypanosoma brucei gambiense HAT and is the most recent key achievement of the Drugs for Neglected Diseases Initiative. It is of high value for HAT endemic countries because it is the first entirely oral treatment for $T$. brucei gambiense HAT and showed promising results in a number of clinical trials. Pharmacokinetic data for SD and MD administration are provided in Table 1.

For the treatment of stage II HAT, penetration through the blood-brain barrier is necessary. However, to date, no human PK studies have investigated FEX PK in CSF or brain tissue.

\subsection{Ivermectin}

Ivermectin (IVM) is available as an oral and topical formulation. Depending on the indication, doses ranging from 150 to $400 \mu \mathrm{g} / \mathrm{kg}$ bodyweight are used, either as a SD or in dosing intervals of 2 weeks up to 2 years. If used for the treatment of Strongyloides stercoralis hyperinfection syndrome and/or disseminated disease, $200 \mu \mathrm{g} / \mathrm{kg}$ bodyweight per day for at least 2 weeks is the recommended dose. Ivermectin should be administered in fasting conditions to increase bioavailability. Studies reporting human SD pharmacokinetics of IVM for different doses are presented in Table 1.

Ivermectin is effective against a number of parasites, including Onchocerca volvulus, Wuchereria bancrofti, and Brugia malayi, and different intestinal helminths and ectoparasites. Although tissue PK data for different compartments would be of interest, only one study on breast milk penetration and one study on skin penetration could be identified that provide sufficient data to be included in this review (Table 2).

\subsection{Mebendazole}

Mebendazole (MEB) belongs to the group of benzimidazoles and is currently available as an oral formulation. The corresponding PK data after oral administration are provided in Table 1. Depending on the indication, it is used in different dosages.

This antiparasitic drug in mainly used for the treatment of infections with nematodes and cestodes, namely echinococcosis, toxocariasis, and trichinellosis. Therefore, penetration of MEB into CSF, cyst fluid in the liver and lung, muscle tissue, eye, and different other organs is crucial for the antiparasitic effects of MEB. Pharmacokinetic studies on tissue penetration of MEB are very limited and only available for echinococcal cyst fluid (Table 2).

\subsection{Melarsoprol}

Melarsoprol (MSP) is an arsenical compound that is available for intravenous injection and is highly toxic. Several different treatment regimens are being used. The PK data after a typical treatment regimen are presented in Table 1. Melarsoprol is used for the management of stage II HAT and one study investigating penetration of MSP into human CSF could be identified (Table 2).

\subsection{Metronidazole}

Metronidazole (MDZ) belongs to the nitroimidazoles and is the most frequently used member of this group. Metronidazole exhibits antibacterial and antiprotozoal activity. It is available for intravenous (i.v.) infusion and oral administration. Doses ranging from $250 \mathrm{mg}$ to $2 \mathrm{~g}$ are routinely used clinically depending on the indication. Pharmacokinetic data after i.v. and oral administration are presented in Table 1. Multiple plasma PK studies in patients with decreased liver and renal function are available and presented in Table 3. One study was excluded from the table because PK data from patients with liver impairment and renal insufficiency were mixed [9].

Regarding the antiparasitic use of MDZ, the main indications are invasive amoebiasis and giardiasis. The protozoan parasite Giardia lamblia that causes giardiasis does not invade extraintestinal tissue. However, for the treatment of amoebiasis, penetration of MZD into liver abscesses and in 
some cases brain tissue is essential. The PK data for MDZ in brain tissue, CSF, and muscle tissue are presented in Table 2.

\subsection{Miltefosine}

Miltefosine (MTF) is only available as an oral formulation. The recommended dose is $50 \mathrm{mg}$ either twice a day or three times a day for 28 days, depending on the weight of the patient. Human PK data for MD administration of MTF are provided in Table 1.

The primary indication for the use of MTF is cutaneous and visceral leishmaniasis. Pharmacokinetic studies that investigated the penetration of MTF into tissue could not be identified in the current literature.

\subsection{Moxidectin}

Moxidectin (MOX) is an anti-helminthic drug that is only available as an oral formulation. The recommended dose is $8 \mathrm{mg}$ as a single dose. The corresponding PK data are provided in Table 1 .

Moxidectin was recently approved for the treatment of onchocerciasis in the USA. Target sites for the treatment of onchocerciasis are the skin, lymph nodes, and the eye. Currently, there are no PK studies in these compartments published; however, penetration data of MOX into human breast milk are presented in Table 2.

\subsection{Nifurtimox}

Nifurtimox (NFT) is available in an oral form and usually administered in doses ranging from 8 to $20 \mathrm{mg} / \mathrm{kg}$ bodyweight per day in three or four divided doses depending on the age of the patients. Single-dose and MD PK data are given in Table 1.

Nifurtimox is primarily used for the treatment of American trypanosomiasis, also named Chagas disease. Unfortunately, we could not identify any relevant tissue penetration studies for NFT.

\subsection{Nitazoxanide}

Nitazoxanide (NZX) is an anti-parasitic and anti-viral drug that is used as an oral dose of $500 \mathrm{mg}$ twice daily. Singledose and MD human PK studies are given in Table 1. The drug is indicated for the treatment of amoebiasis and giardiasis, but no thorough tissue PK studies could be identified.

\subsection{Oxamniquine}

Oxamniquine (OXA) is an anti-schistosomal drug that is used as an oral dose of $15-60 \mathrm{mg} / \mathrm{kg}$ bodyweight. Singledose PK data in healthy volunteers (HV) and patients with advanced hepatosplenic schistosomiasis are presented in Table 1.

Relevant tissue PK studies for OXA could not be identified. This might be attributable to the fact that OXA is primarily indicated for use in intestinal schistosomiasis.

\subsection{Paromomycin}

Paromomycin (PAM) is available as an oral capsule and a formulation for intramuscular (i.m.) injection. The recommended i.m. dose is $15 \mathrm{mg} / \mathrm{kg}$ bodyweight of PAM sulfate once per day. The usual oral dose is $25-35 \mathrm{mg} / \mathrm{kg}$ bodyweight per day of PAM sulfate in three divided doses. It has to be noted that $11 \mathrm{mg}$ of PAM base are equivalent to $15 \mathrm{mg}$ of PAM sulfate. In Table 1, human PK data after i.m. SD administration of PAM to HV and patients with visceral leishmaniasis are presented. Absorption of PAM after oral administration has been reported to be negligible [10].

The indications for treatment with PAM are visceral leishmaniasis, giardiasis, intestinal amebiasis, and cryptosporidiosis. Yet, tissue PK studies for PAM are currently missing.

\subsection{Pentamidine}

Pentamidine (PMD) is an antiprotozoal and anti-pneumocystis drug that is available as a formulation for an i.v. or i.m. injection and inhalation. The usual clinical dose is $4 \mathrm{mg} /$ $\mathrm{kg}$ bodyweight of PMD per day as an i.v. or i.m. injection. Pharmacokinetic studies after SD and MD administration of PMD to T. brucei gambiense- and Pneumocystis cariniiinfected patients could be identified (Table 2).

For the treatment of African trypanosomiasis, penetration of the blood-brain barrier would be beneficial. In the current literature, one study could be identified that investigated penetration of PMD into CSF (Table 2).

One study was excluded from the data of patients with organ impairment shown in Table 3. This study reported a volume of distribution at steady state of $32.4 \pm 45.3 \mathrm{~L}$, a clearance of $329 \pm 58 \mathrm{~L} / \mathrm{h}$, and an AUC from zero to infinity of $0.75 \pm 0.16 \mu \mathrm{g} \mathrm{h} / \mathrm{mL}$ for patients undergoing long-term hemodialysis [11].

\subsection{Pentavalent Antimony}

Pentavalent antimony (SbV) can be administered as meglumine antimoniate (MA) or sodium stibogluconate and formulations for i.v., i.m., and intralesional applications are available. The usual dose of $\mathrm{SbV}$ is $20 \mathrm{mg} / \mathrm{kg}$ bodyweight per day for 10-28 days. Pharmacokinetic data for the i.m. injection of MA and sodium stibogluconate are provided in Table 1. 
Pentavalent antimony is used for the treatment of visceral, cutaneous, and mucocutaneous leishmaniasis. Hence, penetration of $\mathrm{SbV}$ into soft tissue, liver, spleen, bone marrow, and lymph nodes would be beneficial. Only two skin penetration studies on sodium stibogluconate (Table 2) and one skin penetration study on MA could be identified. However, the study on MA was not included because of the poor quality of the data. No other tissue penetration studies were found.

\subsection{Praziquantel}

Praziquantel (PZQ) exhibits antiparasitic activity and is used in a variety of different dosing regimens. Doses typically range from 15 to $40 \mathrm{mg} / \mathrm{kg}$ bodyweight several times per day. For population-based treatment of Opisthorchis viverrini, a $\mathrm{SD}$ of $40 \mathrm{mg} / \mathrm{kg}$ is recommended. The SD and MD PK data after different doses of PZQ are presented in Table 1.

Praziquantel is used to treat schistosomiasis, intestinal fluke infections, liver fluke infections, paragonimiasis, and cysticercosis. Target sites for the treatment of these infections include virtually every organ, but the most important are the biliary system, the liver, the lung, and the central nervous system. In the currently available literature, tissue PK studies in CSF and human breast milk were identified (Table 2). Two studies investigating the concentration of PZQ in cyst fluid in patients with cysticercosis were excluded from Table 2 because of the poor quality of the data $[12,13]$.

\subsection{Pyrimethamine}

Pyrimethamine (PYM) is administered orally and given in doses ranging from 25 to $75 \mathrm{mg}$. A loading dose of $200 \mathrm{mg}$ of PYM is recommended in some cases. It is usually given in combination with sulfadiazine. The data from different plasma PK studies after SD and MD of PYM for different doses are provided in Table 1.

The main antiparasitic indication for PYM use is toxoplasmosis. Toxoplasmosis cysts mainly appear in the brain, eye, bone, and cardiac muscle. Tissue PK studies in CSF, brain tissue, saliva, and human breast milk are available in the literature; however, PK data for the other compartments could not be identified (Table 2).

\subsection{Sulfadiazine}

Sulfadiazine (SDZ) is available as an oral and i.v. formulation and is administered in doses from 1 to $1.5 \mathrm{~g}$ four times per day. Plasma PK parameters after SD and MD administration in HV are available in the literature (Table 1).

For the treatment of parasitic diseases, it is primarily used for toxoplasmosis in combination with PYM. Tissue penetration studies in leg lymph nodes after SD and MD administration are given in Table 2.

\subsection{Suramin}

Suramin (SUR) is administered as an i.v. infusion of $20 \mathrm{mg} /$ $\mathrm{kg}$ bodyweight after administration of a test dose of $5 \mathrm{mg} / \mathrm{kg}$ bodyweight. Only one plasma PK study after MD administration of SUR was identified (Table 1). Suramin is indicated for the treatment of stage I HAT; however, no tissue penetration studies for SUR were found.

\subsection{Tinidazole}

Tinidazole (TDZ) belongs to the group of nitroimidazoles and can be administered as an oral or i.v. formulation. The usual dose is $2 \mathrm{~g}$ of TDZ four times per day. Plasma PK data after oral and i.v. SD are given in Table 1.

Tinidazole is approved for the treatment of giardiasis, amebiasis, and trichomoniasis. Different tissue penetration studies for TDZ are available (Table 2).

Two PK studies were excluded from Table 3 because they were performed in a patient undergoing hemodialysis. In the first study, a single dose of $800 \mathrm{mg}$ of tinidazole was intravenously administered to patients undergoing hemodialysis. In this study, a half-life of $4.25 \pm 0.43 \mathrm{~h}$ and $12.9 \pm 1 \mathrm{~h}$ was reported during and after dialysis, respectively. Additionally, a dialysis clearance of $49.9 \pm 3.2 \mathrm{~mL} / \mathrm{min}$ was reported [14]. The second study in patients undergoing hemodialysis was conducted after oral administration of $2 \mathrm{~g}$ of tinidazole. This dosage led to a half-life between dialysis of $18.37 \pm 3.54 \mathrm{~h}$ and a dialysis clearance of $71 \pm 7.7 \mathrm{~mL} / \mathrm{min}[15]$.

\subsection{Triclabendazole}

Triclabendazole (TBD) is a member of the benzimidazoles and is usually administered as an oral dose of $10 \mathrm{mg} / \mathrm{kg}$ bodyweight. The corresponding plasma pharmacokinetics after SD administration are shown in Table 1.

Triclabendazole is typically used for the treatment of fascioliasis and paragonimiasis. Therefore, good penetration of TBD into the biliary system, the liver, the lung, and the brain would be beneficial. However, no tissue PK studies for TBD could be identified.

\section{Discussion}

Parasites can invade virtually every organ and cause infections that impair the quality of life and even cause death. Many different anti-parasitic agents are available to treat those infections. However, most of these agents were developed decades ago. Some even go back to the very beginnings 
of anti-infective chemotherapy. Despite their long availability, for many drugs, penetration into the particular target tissue has not been investigated. Yet, to effectively treat a parasitic infection, the anti-parasitic agent has to reach the tissue where the parasite resides in sufficiently high concentrations. Knowledge of the amount of tissue penetration would therefore allow for informed analysis of the available treatment schemes and could help optimize treatment of parasitic diseases.

Particularly, knowledge of penetration into CSF and brain tissue would be of immense value for ALB, BZD, EFO, FEX, IVM, MEB, MSP, MDZ, NFT, NZX, PMD, PZQ, PYM, SDZ, SUR, and TDZ. All of these drugs are used for the treatment of diseases that affect the central nervous system. The penetration into the liver or the biliary system is especially interesting for ALB, MEB, MDZ, MTF, NZX, PAM, SbV, PZQ, TDZ, and TBD because those drugs target parasites that regularly invade the liver and biliary system. Lung penetration is pivotal for ALB, AmB, DEC, MEB, PZQ, and TBD, whereas the eye is an important target organ for ALB, DEC, IVM, MEB, MOX, PYM, and SDZ. Penetration of lymphatic tissue and soft tissue is essential for ALB, AmB, DEC, IVM, MTF, MOX, PAM, SbV and ALB, BZD, DEC, IVM, MTF, MOX, PAM, SbV, PZQ, PYM, SDZ, respectively. Evidently, there is an enormous need for tissue PK studies in the field of antiparasitic chemotherapy. The available PK tissue studies on these agents are accumulated in Table 2 and this table clearly shows that for many of the drugs, proper tissue PK studies are lacking. We encourage scientists to fill that gap and help optimize the treatment of parasitic diseases and thereby improve patient care worldwide.

Apart from the PK data of the drug, knowledge of the $\mathrm{PK} /$ pharmacodynamic (PD) relationship of the antimicrobial agent is a prerequisite to employ target attainment analysis and evaluate the existing treatment schemes. The focus of the current review lies on the pharmacokinetics of antiparasitic drugs, yet from a non-systematic screening of literature it is obvious that in contrast to anti-bacterial drugs, the PK/ PD indices that define the efficacy of antiparasitic drugs, have only been investigated very sparsely. More extensive PK/PD analyses are only available for antimalarial drugs, which are not included in the current review. The PK/PD index for AMB has only been investigated for the treatment of fungal infections, but not against parasites. A number of studies demonstrated concentration-dependent antifungal activity of AMB with the peak concentration divided by the minimal inhibitory concentration correlating best with AMB activity [16-18]. For BZD, NFT, and FEX, there is only a single study investigating the relevant PK/PD index. The authors of this study developed a novel time-to-kill assay and were able to show that BDZ, NFT, and FEX all exhibit concentration-dependent trypanocidal activity [19]. The PK parameter of EFO that correlates best with the probability of being cured from late-stage T. brucei gambiense sleeping sickness is the AUC for a dosing interval, according to one study from 2014 [20]. This finding indicates that a combination of concentration and time dependency defines the trypanocidal activity of EFO. The authors developed a population PK model and discovered that a AUC for a dosing interval of the enantiomer L-EFO of $>800 \mathrm{~h} \mu \mathrm{mol} / \mathrm{L}$ was required for cure [20]. Repurposing of IVM for mass administration to tackle malaria has been proposed, as IVM has been shown to kill Anopheles mosquitos feeding on human blood for 28 days after treatment [21]. The PK/PD properties of IVM have been investigated in a recent trial for its mosquitocidal activity and this analysis showed a time-independent relationship of IVM [22]. However, no data on the PK/ PD properties of IVM for antiparasitic use are available in the literature. Concentration-dependent activity was demonstrated for MTZ against the parasite Trichomonas vaginalis with maximum activity at 10-25 times the minimum lethal concentration [23].

The successful treatment of leishmaniasis requires sufficient drug concentrations inside of phagocytes. For MTF, plasma and intracellular human peripheral blood mononuclear cell concentrations are highly correlated and a plasma AUC from day 0 to 28 of $535 \mathrm{mg} \mathrm{d} / \mathrm{L}$ has been proposed as a PK target [24, 25]. The PK/PD relationship of PZQ was investigated in a Schistosoma mansoni mouse model. The authors of the study demonstrated that plasma exposure is not predictive of PZQ anti-schistosomal activity in the mouse model and concluded that the concentration of PZQ in the mesenteric veins (target compartment for $S$. mansoni infections) is probably the driver of efficacy [26]. In contrast to this, a population PK study found a strong correlation of drug AUC in the plasma and parasitological cure of pediatric patients with intestinal schistosomiasis [27]. For the remaining antiparasitic agents, there is a void of studies investigating the $\mathrm{PK} / \mathrm{PD}$ relationship that urgently needs to be filled to improve the treatment of patients infected with parasitic diseases worldwide.

\section{Conclusions}

The current review provides extensive plasma and tissue PK data of antiparasitic drugs and summarizes the currently available literature on the PK/PD relationship of these drugs. There is a considerable amount of data on plasma PK of antiparasitic agents available, but tissue PK has not been thoroughly explored. In addition, there is a lack of studies that investigate the PK/PD relationship of antiparasitic drugs. To improve the treatment of patients with parasitic diseases, we encourage scientists to help fill this gap. 
Acknowledgement Open access funding provided by Medical University of Vienna.

\section{Compliance with Ethical Standards}

Funding No sources of funding were used to assist with the preparation of this review.

Conflict of interest Markus Zeitlinger and Valentin al Jalali have no conflicts of interest that are directly relevant to the content of this review.

Open Access This article is licensed under a Creative Commons Attribution-NonCommercial 4.0 International License, which permits any non-commercial use, sharing, adaptation, distribution and reproduction in any medium or format, as long as you give appropriate credit to the original author(s) and the source, provide a link to the Creative Commons licence, and indicate if changes were made. The images or other third party material in this article are included in the article's Creative Commons licence, unless indicated otherwise in a credit line to the material. If material is not included in the article's Creative Commons licence and your intended use is not permitted by statutory regulation or exceeds the permitted use, you will need to obtain permission directly from the copyright holder.To view a copy of this licence, visit http://creativecommons.org/licenses/by-nc/4.0/.

\section{References}

1. Mitra AK, Mawson AR. Neglected tropical diseases: epidemiology and global burden. Trop Med Infect Dis. 2017;2(3):E36. https://doi.org/10.3390/tropicalmed2030036.

2. Pisarski K. The global burden of disease of zoonotic parasitic diseases: top 5 contenders for priority consideration. Trop Med Infect Dis. 2019;4(1):E44. https://doi.org/10.3390/tropicalme d4010044.

3. Hotez PJ, Alvarado M, Basáñez M-G, et al. The global burden of disease study 2010: interpretation and implications for the neglected tropical diseases. PLoS Negl Trop Dis. 2014;8:e2865.

4. Jung H, Medina L, García L, Fuentes I, Moreno-Esparza R. Absorption studies of albendazole and some physicochemical properties of the drug and its metabolite albendazole sulphoxide. J Pharm Pharmacol. 1998;50:43-8.

5. Lange H, Eggers R, Bircher J. Increased systemic availability of albendazole when taken with a fatty meal. Eur J Clin Pharmacol. 1988;34:315-7.

6. Moriyama B, Torabi-Parizi P, Pratt AK, Henning SA, Pennick G, Shea YR, et al. Pharmacokinetics of liposomal amphotericin B in pleural fluid. Antimicrob Agents Chemother. 2010;54:1633-5.

7. Weiler S, Bellmann-Weiler R, Joannidis M, Bellmann R. Penetration of amphotericin B lipid formulations into pleural effusion. Antimicrob Agents Chemother. 2007;51:4211-3.

8. Malone ME, Corrigan OI, Kavanagh PV, Gowing C, Donnelly M, D'Arcy DM. Pharmacokinetics of amphotericin B lipid complex in critically ill patients undergoing continuous venovenous haemodiafiltration. Int J Antimicrob Agents. 2013;42:335-42.

9. Plaisance KI, Quintiliani R, Nightingale $\mathrm{CH}$. The pharmacokinetics of metronidazole and its metabolites in critically ill patients. J Antimicrob Chemother. 1988;21:195-200.

10. Bissuel F, Cotte L, de Montclos M, Rabodonirina M, Trepo C. Absence of systemic absorption of oral paromomycin during long-term, high-dose treatment for cryptosporidiosis in AIDS. J Infect Dis. 1994;170:749-50.
11. Conte JE. Pharmacokinetics of intravenous pentamidine in patients with normal renal function or receiving hemodialysis. J Infect Dis. 2012;163:169-75.

12. Cobo F, Yarnoz C, Sesma B, Fraile P, Aizcorbe M, Trujillo R, et al. Albendazole plus praziquantel versus albendazole alone as a pre- operative treatment in intra-abdominal hydatidosis caused by Echinococcus granulosus. Trop Med Int Health. 1998;3:462-6.

13. Overbosch D, van de Nes JCM, Groll E, Diekmann HW, Polderman AM, Mattie H. Penetration of praziquantel into cerebrospinal fluid and cysticerci in human cysticercosis. Eur J Clin Pharmacol. 1987;33:287-92.

14. Flouvat B, Imbert C, Dubois D, Temperville B, Roux A, Chevalier $\mathrm{G}$, et al. Pharmacokinetics of tinidazole in chronic renal failure and in patients on haemodialysis. Br J Clin Pharmacol. 1983;15:735-41.

15. Robson RA, Bailey RR, Sharman JR. Tinidazole pharmacokinetics in severe renal failure. Clin Pharmacokinet. 1984;9:88-94.

16. Wiederhold NP, Tam VH, Chi J, Prince RA, Kontoyiannis DP, Lewis RE. Pharmacodynamic activity of amphotericin B deoxycholate is associated with peak plasma concentrations in a neutropenic murine model of invasive pulmonary aspergillosis. Antimicrob Agents Chemother. 2006;50:469-73.

17. Andes D, Stamsted T, Conklin R. Pharmacodynamics of amphotericin $\mathrm{B}$ in a neutropenic-mouse disseminated-candidiasis model. Antimicrob Agents Chemother. 2001;45:922-6.

18. Groll AH, Piscitelli SC, Walsh TJ. Antifungal pharmacodynamics: concentration-effect relationships in vitro and in vivo. Pharmacotherapy. 2001;21:133S-48S.

19. Moraes CB, Giardini MA, Kim H, Franco CH, Araujo-Junior AM, Schenkman S, et al. Nitroheterocyclic compounds are more efficacious than CYP51 inhibitors against Trypanosoma cruzi: implications for Chagas disease drug discovery and development. Sci Rep. 2014;4:1-11.

20. Jansson-Löfmark R, Na-Bangchang K, Björkman S, Doua F, Ashton M. Enantiospecific reassessment of the pharmacokinetics and pharmacodynamics of oral eflornithine against late-stage Trypanosoma brucei gambiense sleeping sickness. Antimicrob Agents Chemother. 2015;59:1299-307.

21. Smit MR, Ochomo E, Aljayyoussi G, et al. Efficacy and safety of high-dose ivermectin for reducing malaria transmission (IVERMAL): protocol for a double-blind, randomized, placebo-controlled, dose-finding trial in Western Kenya. JMIR Res Protoc. 2016;5:e213.

22. Smit MR, Ochomo EO, Waterhouse D, et al. Pharmacokineticspharmacodynamics of high-dose ivermectin with dihydroartemisinin-piperaquine on mosquitocidal activity and QT-prolongation (IVERMAL). Clin Pharmacol Ther. 2019;105:388-401.

23. Nix DE, Tyrrell R, Muller M. Pharmacodynamics of metronidazole determined by a time-kill assay for Trichomonas vaginalis. Antimicrob Agents Chemother. 1995;39:1848-52.

24. Kip AE, Del Mar Castro M, Gomez MA, Cossio A, Schellens JHM, Beijnen JH, et al. Simultaneous population pharmacokinetic modelling of plasma and intracellular PBMC miltefosine concentrations in New World cutaneous leishmaniasis and exploration of exposure-response relationships. J Antimicrob Chemother. 2018;73:2104-11.

25. Dorlo TPC, Rijal S, Ostyn B, et al. Failure of miltefosine in visceral leishmaniasis is associated with low drug exposure. $\mathbf{J}$ Infect Dis. 2014;210:146-53.

26. Abla N, Keiser J, Vargas M, Reimers N, Haas H, Spangenberg T. Evaluation of the pharmacokinetic-pharmacodynamic relationship of praziquantel in the Schistosoma mansoni mouse model PLoS Negl Trop Dis. 2017;11:1-10.

27. Bustinduy AL, Waterhouse D, De Sousa-Figueiredo JC, et al. Population pharmacokinetics and pharmacodynamics of 
praziquantel in Ugandan children with intestinal schistosomiasis: higher dosages are required for maximal efficacy. MBio. 2016;7(4):16. https://doi.org/10.1128/mbio.00227-16.

28. Shenoy RK, Suma TK, John A, Arun SR, Kumaraswami V, Fleckenstein LL, et al. The pharmacokinetics, safety and tolerability of the co-administration of diethylcarbamazine and albendazole. Ann Trop Med Parasitol. 2003;96:603-14.

29. Thomsen EK, Sanuku N, Baea M, et al. Efficacy, safety, and pharmacokinetics of coadministered diethylcarbamazine, albendazole, and ivermectin for treatment of bancroftian filariasis. Clin Infect Dis. 2016;62:334-41.

30. Garcia HH, Lescano AG, Lanchote VL, et al. Pharmacokinetics of combined treatment with praziquantel and albendazole in neurocysticercosis. Br J Clin Pharmacol. 2011;72:77-84.

31. Bekersky I, Fielding RM, Dressler DE, Lee JW, Buell DN, Walsh TJ. Pharmacokinetics, excretion, and mass balance of liposomal amphotericin B (AmBisome) and amphotericin B deoxycholate in humans. Antimicrob Agents Chemother. 2002;46:828-33.

32. Gubbins PO, Amsden JR, McConnell SA, Anaissie EJ. Pharmacokinetics and buccal mucosal concentrations of a 15 milligram per kilogram of body weight total dose of liposomal amphotericin $\mathrm{B}$ administered as a single dose $(15 \mathrm{mg} / \mathrm{kg})$, weekly dose $(7.5 \mathrm{mg} / \mathrm{kg})$, or daily dose $(1 \mathrm{mg} / \mathrm{kg})$ in peripheral stem cell tran. Antimicrob Agents Chemother. 2009;53:3664-74.

33. Walsh TJ, Goodman JL, Pappas P, Bekersky I, Buell DN, Roden $\mathrm{M}$, et al. Safety, tolerance, and pharmacokinetics of high-dose liposomal amphotericin B (AmBisome) in patients infected with Aspergillus species and other filamentous fungi: maximum tolerated dose study. Antimicrob Agents Chemother. 2001;45:3487-96.

34. Walsh TJ, Whitcomb P, Piscitelli S, Figg WD, Hill S, Chanock SJ, et al. Safety, tolerance, and pharmacokinetics of amphotericin B lipid complex in children with hepatosplenic candidiasis. Antimicrob Agents Chemother. 1997;41:1944-8.

35. Molina I, Salvador F, Sánchez-Montalvá A, Artaza MA, Moreno $\mathrm{R}$, Perin L, et al. Pharmacokinetics of benznidazole in healthy volunteers and implications in future clinical trials. Antimicrob Agents Chemother. 2017;61:1-7.

36. Bolla S, Boinpally RR, Poondru S, Devaraj R, Jasti BR. Pharmacokinetics of diethylcarbamazine after single oral dose at two different times of day in human subjects. J Clin Pharmacol. 2002;42:327-31.

37. Na-Bangchang K, Doua F, Konsil J, Hanpitakpong W, Kamanikom B, Kuzoe F. The pharmacokinetics of eflornithine ( $\alpha$-difluoromethylornithine) in patients with late-stage T.b. gambiense sleeping sickness. Eur J Clin Pharmacol. 2004;60:269-78.

38. Tarral A, Blesson S, Mordt OV, et al. Determination of an optimal dosing regimen for fexinidazole, a novel oral drug for the treatment of human African trypanosomiasis: first-in-human studies. Clin Pharmacokinet. 2014;53:565-80.

39. Homeida MM, Malcolm SB, ElTayeb AZ, Eversole RR, Elassad AS, Geary TG, et al. The lack of influence of food and local alcoholic brew on the blood level of Mectizan ${ }^{\circledR}$ (ivermectin). Acta Trop. 2013;127:97-100.

40. Muñoz J, Ballester MR, Antonijoan RM, Gich I, Rodríguez M, Colli E, et al. Safety and pharmacokinetic profile of fixed-dose ivermectin with an innovative $18 \mathrm{mg}$ tablet in healthy adult volunteers. PLoS Negl Trop Dis. 2018;12:1-16.

41. Na-Bangchang K, Kietinun S, Pawa KK, Hanpitakpong W, Na-Bangchang C, Lazdins J. Assessments of pharmacokinetic drug interactions and tolerability of albendazole, praziquantel and ivermectin combinations. Trans R Soc Trop Med Hyg. 2006;100:335-45.
42. Okonkwo PO, Ogbuokiri JE, Ofoegbu E, Klotz U. Protein binding and ivermectin estimations in patients with onchocerciasis. Clin Pharmacol Ther. 1993;53:426-30.

43. Krishnaiah YSR, Veer Raju P, Dinesh Kumar B, Satyanarayana V, Karthikeyan RS, Bhaskar P. Pharmacokinetic evaluation of guar gum-based colon-targeted drug delivery systems of mebendazole in healthy volunteers. J Control Release. 2003;88:95-103.

44. Corti N, Heck A, Rentsch K, Zingg W, Jetter A, Stieger B, et al. Effect of ritonavir on the pharmacokinetics of the benzimidazoles albendazole and mebendazole: an interaction study in healthy volunteers. Eur J Clin Pharmacol. 2009;65:999-1006.

45. Braithwaite PA, Roberts MS, Allan RJ, Watson TR. Clinical pharmacokinetics of high dose mebendazole in patients treated for cystic hydatid disease. Eur J Clin Pharmacol. 1982;22:161-9.

46. Cruz A, Rainey PM, Herwaldt BL, Stagni G, Palacios R, Trujillo R, et al. Pharmacokinetics of antimony in children treated for leishmaniasis with meglumine antimoniate. J Infect Dis. 2007;195:602-8.

47. Burri C, Keiser J. Pharmacokinetic investigations in patients from Northern Angola refractory to melarsoprol treatment. Trop Med Int Health. 2001;6:412-20.

48. Houghton G, Thorne P, Smith J, Templeton R, Collier J. Comparison of the pharmacokinetics of metronidazole in healthy female volunteers following either a single oral or intravenous dose. $\mathrm{Br}$ J Clin Pharmacol. 1979;8:337-41.

49. de C Bergamaschi C, Berto LA, Venâncio PC, Cogo K, FranzMontan M, Motta RHL, et al. Concentrations of metronidazole in human plasma and saliva after tablet or gel administration. $\mathbf{J}$ Pharm Pharmacol. 2014;66:40-7.

50. Salas-Herrera IG, Pearson RM, Jhonston A, Turner P. Concentration of metronidazole in cenical mucus and serum after single and repeated oral doses. J Antimicrob Chemother. 1991;28:283-9.

51. Daneshmend TK, Homeida M, Kaye CM, Elamin AA, Roberts CJ. Disposition of oral metronidazole in hepatic cirrhosis and in hepatosplenic schistosomiasis. Gut. 1982;23:807-13.

52. Del Mar Castro M, Gomez MA, Kip AE, Cossio A, Ortiz E, Navas A, et al. Pharmacokinetics of miltefosine in children and adults with cutaneous leishmaniasis. Antimicrob Agents Chemother. 2017;61:1-11.

53. Korth-Bradley JM, Parks V, Chalon S, Gourley I, Matschke K, Cailleux K, et al. The effect of a high-fat breakfast on the pharmacokinetics of moxidectin in healthy male subjects: a randomized phase I trial. Am J Trop Med Hyg. 2012;86:122-5.

54. González-Martin G, Thambo S, Paulos C, Vásquez I, Paredes J. The pharmacokinetics of nifurtimox in chronic renal failure. Eur J Clin Pharmacol. 1992;42:671-3.

55. Saulnier Sholler GL, Bergendahl GM, Brard L, et al. A phase 1 study of nifurtimox in patients with relapsed/refractory neuroblastoma. J Pediatr Hematol Oncol. 2011;33:25-30.

56. Agarwal S, Solomon WD, Gowda KV, Selvan PS, Ghosh D, Sarkar AK, et al. Bioequivalence study of a fixed dose combination of nitazoxanide and ofloxacin in Indian healthy volunteers. Arzneimittelforschung. 2007;57:679-83.

57. Stockis A, De Bruyn S, Gengler C, Rosillon D. Nitazoxanide pharmacokinetics and tolerability in man during 7 days dosing with $0.5 \mathrm{~g}$ and $1 \mathrm{~g}$ b.i.d. Int J Clin Pharmacol Ther. 2002;40:221-7.

58. Daneshmend TK, Homeida MA. Oxamniquine pharmacokinetics in hepatosplenic schistosomiasis in the sudan. J Antimicrob Chemother. 1987;19:87-93.

59. Musa AM, Younis B, Fadlalla A, et al. Paromomycin for the treatment of visceral leishmaniasis in Sudan: a randomized, openlabel, dose-finding study. PLoS Negl Trop Dis. 2010;4:4-10. 
60. Kanyok TP, Killian AD, Rodvold KA, Danziger LH. Pharmacokinetics of intramuscularly administered aminosidine in healthy subjects. Antimicrob Agents Chemother. 1997;41:982-6.

61. Bronner U, Rais M, Miezan T, Gustafsson L, Rombo L, Ericsson $\mathrm{O}$, et al. Pharmacokinetics and adverse reactions after a single dose of pentamidine in patients with Trypanosoma gambiense sleeping sickness. Br J Clin Pharmacol. 2012;39:289-95.

62. Conte JE, Upton RA, Phelps RT, Wofsy CB, Zurlinden E, Lin ET. Use of a specific and sensitive assay to determine pentamidine pharmacokinetics in patients with AIDS. J Infect Dis. 1986;154:923-9.

63. Bronner U, Doua F, Ericsson Ö, Gustafsson LL, Miézan TW, Rais M, et al. Pentamidine concentrations in plasma, whole blood and cerebrospinal fluid during treatment of Trypanosoma gambiense infection in Côte d'Ivoire. Trans R Soc Trop Med Hyg. 1991;85:608-11.

64. Mandour ME, el Turabi H, Homeida MM, el Sadig T, Ali HM, Bennett JL, et al. Pharmacokinetics of praziquantel in healthy volunteers and patients with schistosomiasis. Trans R Soc Trop Med Hyg. 1990;84:389-93.

65. Leopold G, Ungethüm W, Groll E, Diekmann HW, Nowak H, Wegner DHG. Clinical pharmacology in normal volunteers of praziquantel, a new drug against schistosomes and cestodes: an example of a complex study covering both tolerance and pharmacokinetics. Eur J Clin Pharmacol. 1978;14:281-91.

66. Ridtitid W, Wongnawa M, Mahatthanatrakul W, Punyo J, Sunbhanich M. Rifampin markedly decreases plasma concentrations of praziquantel in healthy volunteers. Clin Pharmacol Ther. 2002;72:505-13

67. Watt G, White NJ, Padre L, Ritter W, Fernando MT, Ranoa $\mathrm{CP}$, et al. Praziquantel pharmacokinetics and side effects in schistosoma japonicum-infected patients with liver disease. J Infect Dis. 1988;157:530-5.

68. Green MD, van Eijk AM, van ter Kuile FO, Ayisi JG, Parise ME, Kager PA, et al. Pharmacokinetics of sulfadoxinepyrimethamine in HIV-infected and uninfected pregnant women in Western Kenya. J Infect Dis. 2007;196:1403-8.

69. Chhonker YS, Bhosale VV, Sonkar SK, et al. Assessment of clinical pharmacokinetic drug-drug interaction of antimalarial drugs $\alpha / \beta$-arteether and sulfadoxine-pyrimethamine. Antimicrob Agents Chemother. 2017;61(9). pii: e02177-16. https:// doi.org/10.1128/aac.02177-16.

70. Mansor S, Navaratnam V, Mohamad M, Hussein S, Kumar A, Jamaludin A, et al. Single dose kinetic study of the triple combination mefloquine/sulphadoxine/pyrimethamine (Fansimef) in healthy male volunteers. Br J Clin Pharmacol. 1989;27:381-6.

71. Weidekamm E, Plozza-Nottebrock H, Forgo I, Dubach UC. Plasma concentrations of pyrimethamine and sulfadoxine and evaluation of pharmacokinetic data by computerized curve fitting. Bull World Health Organ. 1982;60:115-22.

72. Schwartz DE, Weidekamm E, Mimica I, Heizmann P, Portmann R. Multiple-dose pharmacokinetics of the antimalarial drug Fansimef ${ }^{\circledR}$ (pyrimethamine + sulfadoxine + mefloquine) in healthy subjects. Chemotherapy. 1987;33:1-8.

73. Jacobson JM, Davidian M, Rainey PM, Hafner R, Raasch RH, Luft BJ. Pyrimethamine pharmacokinetics in human immunodeficiency virus-positive patients seropositive for Toxoplasma gondii. Antimicrob Agents Chemother. 1996;40:1360-5.

74. Jaser MA, El-Yazigi A, Croft SL. Pharmacokinetics of antimony in patients treated with sodium stibogluconate for cutaneous leishmaniasis. Pharm Res. 1995;12:113-6.

75. Zaghloul IY, Radwan MA, Al Jaser MH, Al Issa R. Clinical efficacy and pharmacokinetics of antimony in cutaneous leishmaniasis patients treated with sodium stibogluconate. J Clin Pharmacol. 2010;50:1230-7.
76. Männistö PT, Mäntylä R, Mattila J, Nykänen S, Lamminsivu U. Comparison of pharmacokinetics of sulphadiazine and sulphamethoxazole after intravenous infusion. J Antimicrob Chemother. 1982;9:461-70.

77. Jordan MK, Burstein AH, Rock-Kress D, Alfaro RM, Pau AK, Kovacs JA, et al. Plasma pharmacokinetics of sulfadiazine administered twice daily versus four times daily are similar in human immunodeficiency virus-infected patients. Antimicrob Agents Chemother. 2004;48:635-7.

78. Collins JM, Klecker RW, Yarchoan R, Lane HC, Fauci AS, Redfield RR, et al. Clinical pharmacokinetics of suramin in patients with HTLV-III/LAV infection. J Clin Pharmacol. 1986;26:22-6.

79. Mattila J, Mannisto PT, Mantyla R, Nykänen S, Lamminsivu U. Comparative pharmacokinetics of metronidazole and tinidazole as influenced by administration route. Antimicrob Agents Chemother. 1983;23:721-5.

80. Chaikin P, Alton KB, Sampson C, Weintraub HS. Pharmacokinetics of tinidazole in male and female subjects. J Clin Pharmacol. 1982;22:562-70.

81. El-Tantawy WH, Salem HF, Mohammed Safwat NAS. Effect of fascioliasis on the pharmacokinetic parameters of triclabendazole in human subjects. Pharm World Sci. 2007;29:190-8.

82. Lecaillon JB, Godbillon J, Campestrini J, Naquira C, Miranda $\mathrm{L}$, Pacheco R, et al. Effect of food on the bioavailability of triclabendazole in patients with fascioliasis. Br J Clin Pharmacol. 1998;45:601-4.

83. Jung H, Hurtado M, Sanchez M, Medina MT, Sotelo J. Plasma and CSF levels of albendazole and praziquantel in patients with neurocysticercosis. Clin Neuropharmacol. 1990;13:559-64.

84. Moskopp D, Lotterer E. Concentrations of albendazole in serum, cerebrospinal fluid and hydatidous brain cyst. Neurosurg Rev. 1993;16:35-7.

85. Morris DL, Chinnery JB, Georgiou G, Stamatakis G, Golematis B. Penetration of albendazole sulphoxide into hydatid cysts. Gut. 1987;28:75-80.

86. Morris DL, Dykes PW, Marriner S, Bogan J, Burrows F, Skeene-Smith $\mathrm{H}$, et al. Albendazole: objective evidence of response in human hydatid disease. JAMA J Am Med Assoc. 1985;253:2053-7.

87. Abdel-Tawab AM, Bradley M, Ghazaly EA, Horton J, El-Setouhy M. Albendazole and its metabolites in the breast milk of lactating women following a single oral dose of albendazole. Br J Clin Pharmacol. 2009;68:737-42.

88. Welte R, Eschertzhuber S, Weiler S, Leitner-Rupprich S, Aigner $\mathrm{M}$, Lass-Flörl C, et al. Biliary amphotericin B pharmacokinetics and pharmacodynamics in critically ill liver transplant recipients receiving treatment with amphotericin B lipid formulations. Int J Antimicrob Agents. 2015;46:325-31.

89. Weiler S, Falkensammer G, Hammerer-Lercher A, Anliker M, Vogelsinger H, Joannidis M, et al. Pulmonary epithelial lining fluid concentrations after use of systemic amphotericin B lipid formulations. Antimicrob Agents Chemother. 2009;53:4934-7.

90. Watanabe A, Matsumoto K, Igari H, et al. Comparison between concentrations of amphotericin B in infected lung lesion and in uninfected lung tissue in a patient treated with liposomal amphotericin B (AmBisome). Int J Infect Dis. 2010;14:220-4.

91. Strenger V, Meinitzer A, Donnerer J, et al. Amphotericin B transfer to CSF following intravenous administration of liposomal amphotericin B. J Antimicrob Chemother. 2014;69:2522-6.

92. Sasaki J, Matsumoto K, Fujishima S, Morita K, Hori S. Pharmacokinetics of a polyene antifungal agent, liposomal amphotericin B (L-AMB), in a severely burned patient. J Chemother. 2014;26:312-4.

93. García-Bournissen F, Moroni S, Marson ME, Moscatelli G, Mastrantonio G, Bisio M, et al. Limited infant exposure to 
benznidazole through breast milk during maternal treatment for Chagas disease. Arch Dis Child. 2015;100:90-4.

94. Ilondu N, Orisakwe OE, Ofoefule S, Afonne OJ, Obi E, Chilaka KC, et al. Pharmacokinetics of diethylcarbamazine: prediction by concentration in saliva. Biol Pharm Bull. 2000;23:443-5.

95. Milord F, Éthier L, Pépin J, Milord F, Loko L, Éthier L, et al. Eflornithine concentrations in serum and cerebrospinal fluid of 63 patients treated for trypanosoma brucei gambiense sleeping sickness. Trans R Soc Trop Med Hyg. 1993;87:473-7.

96. Miyajima A, Hirota T, Sugioka A, et al. Effect of high-fat meal intake on the pharmacokinetic profile of ivermectin in Japanese patients with scabies. J Dermatol. 2016;43:1030-6.

97. Ogbuokiri JE, Ozumba BC, Okonkwo PO. Ivermectin levels in human breast milk. Eur J Clin Pharmacol. 1994;46:89-90.

98. Luder PJ, Witassek F, Weigand K, Eckert J, Bircher J. Treatment of cystic echinococcosis (Echinococcus granulosus) with mebendazole: assessment of bound and free drug levels in cyst fluid and of parasite vitality in operative specimens. Eur J Clin Pharmacol. 1985;28:279-85.

99. Frasca D, Dahyot-Fizelier C, Adier C, Mimoz O, Debaene B, Couet W, et al. Metronidazole and hydroxymetronidazole central nervous system distribution: 1. Microdialysis assessment of brain extracellular fluid concentrations in patients with acute brain injury. Antimicrob Agents Chemother. 2014;58:1019-23.

100. Frasca D, Dahyot-Fizelier C, Adier C, Mimoz O, Debaene B, Couet W, et al. Metronidazole and hydroxymetronidazole central nervous system distribution: 2. Cerebrospinal fluid concentration measurements in patients with external ventricular drain. Antimicrob Agents Chemother 2014;58:1024-7.

101. Jokipii AMM, Myllylä VV, Hokkanen E, Jokipii L. Penetration of the blood brain barrier by metronidazole and tinidazole. $\mathrm{J}$ Antimicrob Chemother. 1977;3:239-45.

102. Karjagin J, Pähkla R, Karki T, Starkopf J. Distribution of metronidazole in muscle tissue of patients with septic shock and its efficacy against Bacteroides fragilis in vitro. J Antimicrob Chemother. 2005;55:341-6.

103. Karjagin J, Pähkla R, Starkopf J. Perioperative penetration of metronidazole into muscle tissue: a microdialysis study. Eur $\mathbf{J}$ Clin Pharmacol. 2004;59:809-13.

104. Bielecka-Grzela S, Klimowicz Phard A. Application of cutaneous microdialysis to evaluate metronidazole and its main metabolite concentrations in the skin after a single oral dose. J Clin Pharm Ther. 2003;28:465-9.

105. Passmore C, McElnay J, Rainey E, D’Arcy P. Metronidazole excretion in human milk and its effect on the suckling neonate. Br J Clin Pharmacol. 1988;26:45-51.

106. Korth-Bradley JM, Parks V, Chalon S, Gourley I, Matschke $\mathrm{K}$, Gossart S, et al. Excretion of moxidectin into breast milk and pharmacokinetics in healthy lactating women. Antimicrob Agents Chemother. 2011;55:5200-4.

107. Bittencourt PRM, Gracia CM, Gorz AM, Mazer S, Oliveira TV. High-dose praziquantel for neurocysticercosis: efficacy and tolerability. Eur Neurol. 1990;30:229-34.
108. Spina-França A, Machado LR, Nóbrega JP, Livramento JA, Diekmann HW, Groll E, et al. Praziquantel in the cerebrospinal fluid in neurocysticercosis. Arq Neuropsiquiatr. 1985;43:243-59.

109. Pütter J, Held F. Quantitative studies on the occurrence of praziquantel in milk and plasma of lactating women. Eur J Drug Metab Pharmacokinet. 1979;4:193-8.

110. Leport C, Meulemans A, Robine D, Dameron G, Vilde JL. Levels of pyrimethamine in serum and penetration into brain tissue in humans. AIDS. 1992;6:1040-1.

111. Weiss LM, Harris C, Berger M, Tanowitz HB, Wittner M, Wittner M. Pyrimethamine concentrations in serum and cerebrospinal fluid during treatment of acute toxoplasma encephalitis in patients with aids. J Infect Dis. 1988;157:580-3.

112. Ahmad R, Rogers H. Salivary elimination of pyrimethamine. $\mathrm{Br}$ J Clin Pharmacol. 1981;11:101-2.

113. Edstein M, Veenendaal J, Newman K, Hyslop R. Excretion of chloroquine, dapsone and pyrimethamine in human milk. Br J Clin Pharmacol. 1986;22:733-5.

114. al Jaser M, El-Yazigi A, Kojan M, Croft SL. Skin uptake, distribution, and elimination of antimony following administration of sodium stibogluconate to patients with cutaneous leishmaniasis. Antimicrob Agents Chemother. 1995;39:516-9.

115. Bergan T, Engeset A, Olszewski W. Pharmacokinetics of oral co-trimazine and the penetration of its components sulfadiazine and trimethoprim into peripheral human lymph. Chemotherapy. 1986;32:209-21.

116. Evaldson G, Lindgren S, Nord C, Rane A. Tinidazole milk excretion and pharmacokinetics in lactating women. Br J Clin Pharmacol. 1985;19:503-7.

117. Klimowicz A, Nowak A, Bielecka-Grzela S. Penetration of tinidazole into skin blister fluid following its oral administration. Eur J Clin Pharmacol. 1992;43:523-6.

118. Adjepon-Yamoah K, Edwards G, Breckenridge A, Orme M, Ward $\mathrm{S}$. The effect of renal disease on the pharmacokinetics of diethylcarbamazine in man. Br J Clin Pharmacol. 1982;13:829-34.

119. Loft S, Sonne J, Døssing M, Andreasen PB. Metronidazole pharmacokinetics in patients with hepatic encephalopathy. Scand J Gastroenterol. 1987;22:117-23.

120. Houghton G, Dennis M, Gabriel R. Pharmacokinetics of metronidazole in patients with varying degrees of renal failure. Br J Clin Pharmacol. 1985;19:203-9.

121. Muscara M, Pedrazzoli J, Miranda E, Ferraz J, Hofstatter E, Leite $\mathrm{G}$, et al. Plasma hydroxy-metronidazole/metronidazole ratio in patients with liver disease and in healthy volunteers. Br J Clin Pharmacol. 1995;40:477-80.

122. Farrell G, Baird-Lambert J, Cvejic M, Buchanan N. Disposition and metabolism of metronidazole in patients with liver failure. Hepatology. 1984;4:722-6.

123. Lau AH, Evans R, Chang CW, Seligsohn R. Pharmacokinetics of metronidazole in patients with alcoholic liver disease. Antimicrob Agents Chemother. 1987;31:1662-4.

124. John EC, Upton RA, Lin ET. Pentamidine pharmacokinetics in patients with AIDS with impaired renal function. J Infect Dis. 1987;156:885-90. 